 \\ DOI: $\underline{10.33716 / \text { bmedj.1045913 }}$}

\section{A Risk to consider in the pandemic: Weight gain in youths}

${ }^{1}$ Asst. Prof., Adıyaman University, Faculty of Health Sciences, Department of Child Health and Diseases Nursing, Adıyaman, Turkey

${ }^{2}$ R. A., Harran University, Faculty of Health Sciences, Department of Child Health and Diseases Nursing, Şanlıurfa, Turkey,

${ }^{3}$ Assoc. Prof., İnönü University, Faculty of Nursing,Department of Child Health and Diseases Nursing, Malatya, Turkey,

Sorumlu Yazar: Mürşide Zengin, Asst. Prof., Adiyaman University, Faculty of Health Sciences, Department of Child Health and Diseases Nursing, Adıyaman, Turkey E-mail:mzengin@adiyaman.edu.tr Telefon: +90 41622338 00-4629

Başvuru Tarihi: 25.12 .2021 Kabul Tarihi: 07.02.2022 Yayınlanma Tarihi: 28.02 .2022

Atıf İçin: Mürşide Zengin, Mehmet Emin Düken, Emriye Hilal Yayan, A Risk to consider in the pandemic: Weight gain in youths. 2022;6(1):17-23.

\section{ABSTRACT}

Objective: This study was aimed to evaluate whether the lockdown for outbreak will pose a risk in terms of weight gain in youths by determining daily activity levels, screen time and calorie amounts. Material and Method: This prospective and descriptive study was conducted during the initial stage of the Coronavirus Disease 2019 (COVID-19) lockdown. The research data were collected from youths aged 15-20 years, residing in a province in the southeast of Turkey. Research data were collected through the online interview method from a total of 67 youths residing in the family health center area of a district in the specified province. Results: The daily physical activity time was $36.41 \pm 49.09$ minutes, their sleep time was $9.34 \pm 1.58$ hours, and screen time was $7.70 \pm 4.20$ hours of the youths. Of the youths, $44.8 \%$ had taken more necessary than daily calories. It was found that youths were gained $2.13 \pm 2.02 \mathrm{~kg}$ during the initial stage of the COVID-19 lockdown. Conclusion: The results of the research showed that nearly half of the youths received more calories than they should take daily, they consumed unhealthy foods more frequently, their daily physical activity time was low, and their screen times were long during the initial stage of the COVID-19 lockdown. It was thought to be important to take necessary precautions against a possible global childhood obesity crisis in the future. In line with the research findings, it can be said that young people should be evaluated separately in terms of nutrition and weight gain in future pandemics.

Keywords: Feeding behavior; outbreaks, youth; weight gain

\section{öz}

Amaç: Bu çalışmada, salgındaki kapanmada gençlerin günlük aktivite düzeylerinin, ekran sürelerinin ve kalori miktarlarının belirlenerek, kapanmanın gençlerde kilo alımı açısından oluşturacağı riskin belirlenmesi amaçlandı. Gereç ve Yöntem: Prospektif ve tanımlayıcı tipteki çalışma, Koronavirus Hastalığı 2019 (KOVID-19) kapanmasının ilk aşamasında gerçekleştirildi. Araştırma verileri Türkiye'nin Güneydoğusundaki bir ilde ikamet eden 15-20 yaş arası gençlerden toplandı. Araştırma verileri, belirtilen ilin bir ilçesindeki aile sağlığı merkezi bölgesinde ikamet eden toplam 67 gençten online görüşme yöntemiyle toplandı. Bulgular: Gençlerin günlük fiziksel aktivite süresi $36.41 \pm 49.09$ dakika, uyku süresi $9.34 \pm 1.58$ saat ve ekran başında kalma süresi $7.70 \pm 4.20$ saatti. Gençlerin \%44.8'i günlük alması gereken kaloriden daha fazlasını aldı. KOVID-19 kapanmasının ilk aşamasında gençlerin $2.13 \pm 2.02 \mathrm{~kg}$ aldığı tespit edildi. Sonuç: Araştırma sonuçları, KOVID-19 kapanmasının ilk aşamasında gençlerin yaklaşık yarısının günlük almaları gerekenden daha fazla kalori aldıklarını, sağlıksız yiyecekleri daha sık tükettiklerini, günlük fiziksel aktivite sürelerinin düşük olduğunu ve ekran sürelerinin uzun olduğunu gösterdi. Gelecekte olası bir küresel çocukluk çağı obezite krizine karşı gerekli önlemlerin alınmasının önemli olduğu düşünülmektedir. Araştirma bulguları doğrultusunda ileride olası pandemilerde de gençlerin beslenme ve kilo alımı açısından ayrıca değerlendirilmesi gerektiği söylenebilir.

Anahtar Kelimeler: beslenme davranışı; salgınlar; genç; ağırlık artışı 


\section{INTRODUCTION}

Recently, the COVID-19 that affects almost all countries worldwide, causing high mortality and morbidity, has been declared as a pandemic and global health emergency by the World Health Organization.(1-5) Public health measures applied to prevent the person-to-person spread of the virus are isolation and quarantine, social distancing and community containment.(6) As a natural consequence of the outbreak, some changes occurred in the daily routines of young people such as eating habits and social activities. $(5,7-9)$ In order to protect the social distance, schools are closed in many countries and distance learning models are implemented.(10)

The world is experiencing an extraordinary, life-altering challenge due to the COVID-19 pandemic.(11)Based on the COVID-19 Impact on Lifestyle Change Survey (COINLICS) Turkey is one of the countries with the highest number of cases of COVID-19.(12) Since the first coronavirus case occurred in Turkey in March 2020, various isolation measures have been taken to prevent the spread of the virus.(13) Schools were closed and after a circular was issued by the Ministry of Interior, individuals under the age of 20 were prohibited from leaving home.(14) Although strict isolation and quarantine measures for youth reduce the spread of the disease, it brings with it various problems. The closure of schools, social isolation and house arrest resulted in a decrease in the physical activity levels of children and adolescents, increase in sedentary lifestyle and screen time with the possibility of stress-induced indulgence in high calorie dense and sugary foods, resulting in higher susceptibility to weight gain. $(5,15,16)$

The COVID-19 quarantine has caused significant changes in everyday life.(17) Previous studies discussed the decrease in daily activity level, increase in screen time, change in eating habits, and the possibility of an increase in weight gain of young people during the pandemic. $(5,11,16)$ However, to the best of our knowledge, no studies have evaluated the relation of the daily calorie intake, screen time and activity levels of healthy youths during the initial stage of the COVID-19 lockdown in Turkey. Especially in youths who spend 24 hours a day at home, determining the changes in the diet, daily calories intake and the level of activity is important in order to predict the possible weight changes that may occur during the outbreak. Uncertainty about how long the outbreak and isolation measures will take increases the concern about possible weight gain and the risk of obesity in youths. In the present study, it is aimed to evaluate whether the outbreak will pose a risk in terms of weight gain in youths by determining daily activity levels and calorie amounts during 7 days.

\section{MATERIAL AND METHOD}

\section{Study design and Sampling}

This was a prospective and descriptive study. Research data were collected online between May and June 2020, in which COVID-19 cases reached its peak in Turkey. The study population consisted of youths aged between $15-20$ years that residing in a province in Southeastern Turkey. Study data were collected from youths residing in the family health center area of a district in the specified province. The purposive and convenience sampling technique was used to reach individuals with similar sociocultural characteristics. All the individuals who agreed to participate in the study were included in the study.

The criteria for being included in the study were specified as being 15-20 years of age, not having a diagnosis of metabolic or endocrine system disease, and volunteering to participate in the study. The exclusion criterion was determined as the presence of any psychiatric illness, the use of medication that could cause weight gain during the pandemic period, and the questionnaire form being incomplete or incorrectly completed. This study included data of 67 youths who met the inclusion criteria and completed the questionnaire form in full. The acceptance rate of the participants in the study was $83.75 \%$.

\section{Data collection}

Research data were collected through the online interview method during the initial stage of the COVID-19 lockdown. Firstly, youths who met the sample selection criteria were reached by phone and were informed about the aim of the study. Then, informed consent form and data collection form were sent to those who were willing to participate in the study.

The data collection form included questions about youths' age, gender, nutrients they consumed within 24 hours, the amount of each nutrient, and their sleep, physical activity, and screen times. This form was created according to the literature $(7,8,11,15,16,17)$ and finalised by using the views of four experts, who included two lecturers from the Department of Children's Health and Diseases Nursing, and two experts from the Nutrition and Dietetics.

Youths were explained that a form, where they would enter the amount of food they consume at the end of the day and their sleep, physical activity, and screen time in detail for seven days, would be sent online by the researchers. During this period, they were asked to continue their daily diets and physical activities as before. For seven days, the link of the data collection form was sent to the participants online at the end of each day to ensure that participants entered their 24-hour nutrient amount and physical activity level. Seven-day calorie intake, and physical activity, sleep, and screen time were calculated for each participant. 


\section{Statistical analysis}

The seven-day overall calorie intake was determined by calculating the nutritional values of the foods youths consumed daily. Harris-Benedict equation was used to determine the total daily calorie need of the youths (https://www. birbes.com/enerji-gereksinimi-hesaplama-araci-harris-benedict/).

Data was analysed using the Statistical Package for the Social Sciences (SPSS) version 22.0 for Windows. Data was then analysed using descriptive statistics. From descriptive statistics, mean, standard deviation, frequency and percentage distribution were used. Shapiro-Wilk test was implemented to determine whether sample data were normally distributed. The comparison of the amount of calories intake with several variables was performed using analysis of variance (ANOVA) test. A $p$ value of $<0.05$ was considered statistically significant and results were evaluated at a $0.95 \%$ confidence interval.

\section{Ethical Declaration}

Before conducting the study, necessary permissions were obtained from the IU Clinical Investigations Ethical Committee (Decision No: 2020/699). To conduct the study, the necessary permission was obtained from Republic of Turkey General Directorate of Health Services of the Ministry of Health, COVID-19 Scientific Research Evaluation Commission (2020-0507T17_26_09). The present study was designed based on the Helsinki Principles. The informed consent of both children and parents were taken in the digital environment. Due to ethical requirements on anonymity and confidentiality, we did not collect contact details and personal information from the respondents.

\section{RESULTS}

The mean age of the participants was $17.70 \pm 1.54$ years and $55.2 \%$ were female $(n=37)$. All youths included in the study were students $(n=67)$. Height and weight values were $165.95 \pm 7.01 \mathrm{~cm}$ and $61.28 \pm 8.86 \mathrm{~kg}$, respectively. Table 1 presents the age, height, weight, and body mass index (BMI) values.

The daily physical activity time of youths was $36.41 \pm 49.09$ minutes, their sleep time was $9.34 \pm 1.58$ hours, time spent on the smartphone was $4.04 \pm 2.43$ hours, and their screen time was $7.70 \pm 4.20$ hours (Table 2).

Table 1. Some characteristic variables of youths $(n=67)$

\begin{tabular}{|l|c|c|}
\hline Variables & $\overline{\mathbf{X}} \pm$ SD & Min-Max Values \\
\hline Age (year) & $17.70 \pm 1.54$ & $15-20$ \\
\hline Weight $(\mathrm{kg})$ & $61.28 \pm 8.86$ & $44-87$ \\
\hline Height $(\mathrm{cm})$ & $165.95 \pm 7.01$ & $150-192$ \\
\hline BMI $\left(\mathrm{kg} / \mathrm{cm}^{2}\right)$ & $22.19-2.46$ & $16.40-27.30$ \\
\hline
\end{tabular}

$\overline{\mathrm{X}}$ : Mean; SD: Standard deviation; Min: Minimum value; Max: Maximum value

The distribution of data on the nutritional characteristics of youths participating in the study is given in Table 3 . Based on the table, the average daily calorie intake of youths was $2130.08 \pm 788.68 \mathrm{kcal}$, and the recommended average daily calorie intake was $1916.10 \pm 459.69 \mathrm{kcal}$. The mean weight gain was observed to be $0.63 \pm 0.66 \mathrm{~kg}$ over a period of seven days, and $2.13 \pm 2.02 \mathrm{~kg}$ during the pandemic period. Of the youths, $44.8 \%$ had taken more calories than they should.

Table 2. Activity levels and screen time of youths ( $n=67)$

\begin{tabular}{|l|c|c|}
\hline Variables & $\overline{\mathbf{X}} \pm$ SD & Min-Max Values \\
\hline Physical activity time $(\mathrm{m} / \mathrm{d})$ & $36.41 \pm 49.09$ & $0-300$ \\
\hline Sleep time $(\mathrm{h} / \mathrm{d})$ & $9.34 \pm 1.58$ & $4-13$ \\
\hline Homework time $(\mathrm{m} / \mathrm{d})$ & $75.22 \pm 139.48$ & $0-600$ \\
\hline Reading time $(\mathrm{m} / \mathrm{d})$ & $10.76 \pm 40.00$ & $0-240$ \\
\hline Smartphone usage time $(\mathrm{h} / \mathrm{d})$ & $4.04 \pm 2.43$ & $0-11$ \\
\hline Screen time $(\mathrm{h} / \mathrm{d})$ & $7.70 \pm 4.20$ & $0-15$ \\
\hline
\end{tabular}

$\overline{\mathrm{X}}$ : Mean; SD: Standard deviation; Min: Minimum value; Max: Maximum value; m / d: minutes/day; h / d: hours/day

During the seven-day period, $58.2 \%$ of youths reported that they consumed meat and meat products one to three times, $44.8 \%$ consumed wheat products four to six times, $47.8 \%$ consumed fresh vegetables and fruits four to six times, and $55.2 \%$ consumed junk food four to six times.

Table 4 shows the relationship between the daily calorie intake of youths and some variables. According to the table; BMI values, the weight gained during the pandemic, and daily sleep time of youths, who received more calories than necessary, were found to be significantly higher compared to other youths $(p<0.05)$. The physical activity time of youths, who were found to intake calories more than necessary, were lower than they needed. There was no significant difference between screen time and daily calorie intake of youths ( $p>0.05)$. 
Table 3. The distribution of nutritional characteristics of youths

\begin{tabular}{|c|c|c|}
\hline Variables & $\overline{\mathrm{X}} \pm \mathrm{SD}$ & Min-Max Values \\
\hline Daily calorie intake (kcal) & $2130.08 \pm 788.68$ & $614-3671$ \\
\hline Recommended daily calorie intake (kcal) & $1916.10 \pm 459.69$ & $1290-3175$ \\
\hline Weight gained during 7 days (kg) & $0.63 \pm 0.66$ & $0-2$ \\
\hline \multirow[t]{2}{*}{ Weight gained during pandemic (kg) } & $2.13 \pm 2.02$ & $(-3)-(+6)$ \\
\hline & $\mathbf{n}$ & $\%$ \\
\hline \multicolumn{3}{|l|}{ Daily calorie intake } \\
\hline Less than necessary & 15 & 22.4 \\
\hline Equal to necessary & 22 & 32.8 \\
\hline More than necessary & 30 & 44.8 \\
\hline \multicolumn{3}{|l|}{$\begin{array}{l}\text { Frequency of consuming certain foods } \\
\text { during seven days }\end{array}$} \\
\hline \multicolumn{3}{|l|}{ Meat products } \\
\hline $1-3$ & 39 & 58.2 \\
\hline $4-6$ & 23 & 34.3 \\
\hline 7 & 5 & 7.5 \\
\hline \multicolumn{3}{|l|}{ Wheal Products (White bread, pasta etc.) } \\
\hline $1-3$ & 9 & 13.4 \\
\hline $4-6$ & 30 & 44.8 \\
\hline 7 & 28 & 41.8 \\
\hline \multicolumn{3}{|l|}{ Fresh vegetables and fruits } \\
\hline $1-3$ & 16 & 23.9 \\
\hline $4-6$ & 32 & 47.8 \\
\hline 7 & 19 & 28.3 \\
\hline \multicolumn{3}{|l|}{ Junk food (chips, coke, chocolate etc.) } \\
\hline $1-3$ & 12 & 17.9 \\
\hline $4-6$ & 37 & 55.2 \\
\hline 7 & 18 & 26.9 \\
\hline Total & 67 & 100 \\
\hline
\end{tabular}

$\bar{X}$ : Mean; SD: Standard deviation; Min: Minimum value; Max: Maximum value;

Table 4. The effects of the daily calorie intake of youths on some variables $(n=67)$

\begin{tabular}{|l|c|c|c|c|c|}
\hline & \multicolumn{3}{|c|}{ Daily Calorie Intake } & \\
\hline & $\begin{array}{c}\text { Less than } \\
\text { necessary }\end{array}$ & $\begin{array}{c}\text { Equal to } \\
\text { necessary }\end{array}$ & $\begin{array}{c}\text { More than } \\
\text { necessary }\end{array}$ & Test Value & $\mathbf{p}^{*}$ \\
\hline BMI & $21.74 \pm 2.57$ & $21.36 \pm 2.63$ & $23.03 \pm 2.15$ & 3,345 & 0.042 \\
\hline Weight gained (kg) & $1.53 \pm 1.99$ & $1.40 \pm 1.59$ & $2.96 \pm 2.07$ & 5,16 & 0.008 \\
\hline Sleep time (h / d) & $8.26 \pm 1.70$ & $9.40 \pm 1.59$ & $9.83 \pm 1.26$ & 5.626 & 0.006 \\
\hline $\begin{array}{l}\text { Physical activity } \\
\text { time (m / d) }\end{array}$ & $96.00 \pm 68.92$ & $15.90 \pm 21.96$ & $21.66 \pm 21.50$ & 24,52 & 0.000 \\
\hline Screen time (h / d) & $7.30 \pm 3.75$ & $7.45 \pm 3.34$ & $8.07 \pm 5.01$ & 0.219 & 0.804 \\
\hline
\end{tabular}

BMI: Body Mass Index; $\mathrm{m}$ / d: minutes/day; h / d: hours/day

* ANOVA test was used. 


\section{DISCUSSION}

This study aimed to be able to predict whether the risk of weight gain and obesity among youths increased during the COVID-19 lockdown period by determining their daily calorie intake, physical activity level, and screen time. The results of the research showed that nearly half of the youths had taken more calories per day than they should, they consumed unhealthy foods (e.g. chips, chocolate, etc.) more frequently and their daily physical activity time was low whereas their screen time was high.

World Health Organization (WHO) recommend that all children and adolescents (5-17 years) should do at least 60 minutes of moderate to vigorous-intensity physical activity in a day and all adults (over 18 years) should do at least 150 minutes of moderate-intensity physical activity throughout the week, or at least 75 minutes of vigorous-intensity physical activity throughout the week.(18) However, the physical activity levels of children and adolescents have been reported to decrease significantly due to the pandemic.(15) In this study, the daily physical activity time of youths was determined to be $36.41 \pm 49.09$ minutes. This value is very below the period recommended by the World Health Organization (WHO). Similar to the findings of the present research, studies have drawn attention to the decrease in the physical activity level of children and adolescents during the pandemic period. $(5,16)$ Children typically obtain their daily physical activity through active travel to school; physical education and recess; organised sports, games, and dance; active play; and spending time in playgrounds and parks. Conversely, most of their sedentary time and sleep are accumulated at home.(19) In the study conducted by Yang et al., more than half of the participants reported that their physical activity times were decreased during the initial stage of the COVID-19 lockdown in China.(20)the Chinese government implemented strict lockdown measures to control the spread of infection. The impact of the COVID-19 lockdown on eating habits and lifestyles in the general population is unclear. This cross-sectional study was conducted via an online survey to obtain an overview of the food access, food intake, and physical activity of Chinese residents during the initial stage of the COVID-19 lockdown, and to investigate the association between staying at home/working from home and changes in eating habits and lifestyles. A total of 2702 participants $(70.7 \%$ women In a study conducted in Lithuania, $60.6 \%$ of participants reported a decrease in physical activity.(17) Significantly decreased physical activity time among youths can be attributed to the fact that they spend almost the entire day at home due to the closure of schools because of the pandemic.

The present research revealed that the screen times of the youths were very high $(7.70 \pm 4.20$ hours). Pietrobelli et al. (21) reported in their study involving children with obesity that the screen time of youths increased significantly (baseline: 2.76 \pm 1.64 , lockdown: $7.61 \pm 2.13$ ) during the pandemic period. In a different study, parents stated that the time their children spent on the Internet increased during the pandemic period.(22) It can be said that screen time increases among youths in parallel with the social disruption caused by the pandemic and the increase in the time spent at home.

It was predicted that the COVID-19 pandemic will aggravate the childhood obesity epidemic and lead to significant weight gain in school children by creating an unprecedented obesogenic environment.(19) This research showed that $44.8 \%$ of youths consumed more calories than they should take daily and gained weight more than $2 \mathrm{~kg}$ in the early period of the pandemic. In a study from Turkey, involving children aged seven to 13 years and their parents, $41.5 \%$ of the parents reported that their children gained weight during the lockdown.(22) In a study by Pellegrini et al. evaluating patients with obesity after one-month lockdown during the COVID-19 pandemic in Italy, the authors reported that the weight gain was about 1.5 $\mathrm{kg}, 40 \%$ of the individuals ate more, level of physical activity reduced, and consumption of unhealthy foods increased.(23) A cohort study conducted in France reported that participants experienced an average weight change of $1.8 \mathrm{~kg}$ during the lockdown, the lockdown led to unhealthy nutritional behaviors and might increase the nutrition-related burden of disease if maintained in the long term.(24)the coronavirus disease (COVID-19 Wand et al. reported that when children were not attending school, they were less physically active, the time they spend in front of the screen increased, their sleep patterns were disrupted and they had a more unhealthy diet, causing weight gain and cardiovascular problems.(7) Storz (2020) emphasized that the school closures increased screen time and unhealthy weight gain in children, triggered irregular sleep habits and reduced their physical activity level. Furthermore, stress-related eating is reported to increase due to quarantine, lockdown, and social distance.(25) Taken together, the findings of the present research suggest that pandemic and social isolation measures may increase the risk of weight gain in young people and cause an increase in obesity prevalence. The research was conducted in the early stages of the pandemic (the second and third months after the first cases were reported in Turkey), and therefore, we believe that the weight gain in youths may be even greater in later periods.

The present study further showed that unhealthy food consumption was also very high in youths, suggesting that excess calories may have been taken from unhealthy foods. It is believed that the consumption of packaged products by youths has increased due to the fact that they are immobile and spend most of the day in front of the screen or they demonstrate stress-related unhealthy eating behaviors due to the pandemic. Various studies reported that unhealthy food consumption increased during the pandemic period. In a study investigating the effect of the COVID-19 pandemic on children, $27.3 \%$ of the parents reported that their children ate more during the pandemic and that there was an increase in their children's consumption of junk food.(26)with direct consequences on children's nutrition. We aimed to investigate the effects of the lockdown imposed in Italy on FI and changes in eating habits and body weight in the pediatric population 6 months after the beginning of the pandemic through a cross-sectional online survey proposed to parents of children \&lt; 18 and living in Italy. Among 5811 respondents, most of whom were Italian, living in Northern Italy, and with a wealthy household economy, 8.3\% reported that their families were at risk of FI before the appearance of SARS-CoV-2 and, alarmingly, this percentage increased to $16.2 \%$ after the pandemic began, with households from Southern Italy being more at risk. Moreover, $27.3 \%$ 
of the parents reported that their children were eating more; an increase in junk food (26). In another study, most of the families participating in the study stated that the total amount of food in their homes increased during the pandemic, and about a third of them reported an increase in unhealthy foods (e.g. high-calorie, sweet foods) and fresh foods (e.g. fruits, vegetables).(27) Although this increase may be the result of anxiety arising from restrictions and prohibitions, it may also be an inevitable consequence of an increase in food intake.

\section{Limitations of the study}

There are several limitations in this study. Research results are generalizable only to the research universe and do not represent all youths in Turkey. The most important limitation of the study is that the nutritional habits of youths during the pandemic period are evaluated; their pre-pandemic situation is unknown. Seven-day calorie intake, frequency of specific foods consumed, physical activity levels, and screen times were collected prospectively and were considered as their usual eating habits. Finally, this research was conducted during the initial stage of the COVID-19 lockdown. It is possible that there will be differences in the dietary habits, sleep, and activity time of young people during different periods of the pandemic.

\section{CONCLUSION}

The results of the research showed that during the lockdown period lockdown nearly half of the youths had taken more calories per day than they should, they consumed unhealthy foods (packaged products) more frequently and their daily physical activity time was low whereas their screen time was long. Daily sleep time of youths, who received more calories than necessary, were found to be significantly higher compared to other youths. During the lockdown period, youths should be urgently supported on healthy nutrition and activity.

To the best of our knowledge, this is the first study investigating the risk of weight gain by evaluating calorie changes in healthy youths during the pandemic period in Turkey. There is a need for further studies revealing the relationship of changes in the nutritional habits of youths with their physical and mental health and investigating the effects of interventions on reducing the factors affecting unhealthy diets. It was important to encourage youths to decrease their calorie amounts, sleep and screen time, and increase physical activity time during lockdown periods. Studies are needed to investigate the effect of the lockdown in the pandemic on changes of daily lifestyle and the long-term effects of this change on people. It is important to take necessary precautions against a possible global childhood obesity crisis in the future. In line with the research findings, it can be said that young people should be evaluated separately in terms of nutrition and weight gain in future pandemics.

\section{ACKNOWLEDGEMENTS}

Conflict of nterests: The author declares that for this article they have no actual, potential or perceived conflict of interests.

Ethical Declaration: Ethical committee approval was obtained from the IU Clinical Investigations Ethical Committee (Decision No: 2020/699).

Financial Support: The authors declared that this study received no financial support.

Author Contribution: Concept: MZ, MED, EHY; Desing MZ, MED, EHY; Data collecting: MZ, MED; Statistical analysis: MZ, EHY; Literature review: MZ, EHY; Writing: MZ, EHY; Critical review: MZ, MED, EHY.

\section{REFERENCES}

1. World Health Organization. (2020). Coronavirus (COVID-19) events as they happen. Available at: https://www.who.int/ emergencies/diseases/novel-coronavirus-2019/events-as-they-happen. Accessed 22 May 2020.

2. Panahi L, Amiri M, Pouy S. Clinical characteristics of COVID-19 infection in new- borns and pediatrics: A Systematic Review. Arch Acad EmergencyMedicine. 2020;8(1):e50. DOI:10.1101/2020.04.05.20053983

3. Hong H, Wang Y, Chung HT, Chen CJ. Clinical characteristics of novel coronavirus disease 2019 (COVID-19) in newborns, infants and children. Pediatr Neonatol. 2020;61(2):131-2. DOI: 10.1016/j.pedneo.2020.03.001.

4. Chen H, Guo J, Wang C, Luo F, Yu X, Zhang W, et al. Clinical characteristics and intrauterine vertical transmission potential of COVID-19 infection in nine pregnant women: a retrospective review of medical records. Lancet. 2020;395(10226):809-15. DOI:10.1016/S0140-6736(20)30360-3

5. Rundle AG, Park Y, Herbstman JB, Kinsey EW, Wang YC. COVID-19-related school closings and risk of weight gain among children. Obesity. 2020; 28(6):1008-1009. DOI:10.1002/oby.22813

6. Wilder-Smith A, Freedman DO. Isolation, quarantine, social distancing and community containment: Pivotal role for old-style public health measures in the novel coronavirus (2019-nCoV) outbreak. Journal of Travel Medicine. 2020; 13;27(2):taaa020. DOI:10.1093/jtm/taaa020

7. Wang G, Zhang Y, Zhao J, Zhang J, Jiang F. Mitigate the effects of home confinement on children during the COVID-19 outbreak. The Lancet. 2020; 21;395(10228):945-947. 
8. Dalton L, Rapa E, Stein A. Protecting the psychological health of children through effective communication about COVID-19. Lancet Child Adolesc Heal. 2020;4(5):346-7. DOI:10.1016/S0140-6736(20)30547-X

9. Rodríguez MÁ, Crespo I, Olmedillas H. Exercising in times of COVID-19: what do experts recommend DOIng within four walls? Rev Española Cardiol. 2020;73(7):527-529. DOI:10.1016/j.rec.2020.04.001

10. Golberstein E, Gonzales G, Meara E. How do economic downturns affect the mental health of children? Evidence from the National Health Interview Survey. Heal Econ (United Kingdom). 2019;28(8):955-70. DOI:10.1002/hec.3885

11. Jia P, Liu L, Xie X, Yuan C, Chen H, Guo B, et al. Changes in dietary patterns among youths in China during COVID-19 epidemic: The COVID-19 impact on lifestyle change survey (COINLICS). Appetite. 2021;158:105015. DOI:10.1016/j. appet.2020.105015

12. Worldometer. (2020). COVID-19 Coronavirus pandemic. Available at: https://www.worldometers.info/coronavirus/. Accessed 22 May 2020.

13. Onay ZR, Şişmanlar Eyüboğlu T, Aslan AT. Çocuklarda COVID-19. (COVID-19 in Children). Eurasian J Pulmonol. 2020;13547.

14. T. C. Ministry of Interior. (2020). Şehir Giriş/Çıkış Tebirleri ve Yaş Sınırlaması Genelgesi. (City Entry/Exit Regulations and Age Limitation Circular). Available at: https://www.icisleri.gov.tr/sehir-giriscikis-tebirleri-ve-yas-sinirlamasi. Accessed 18 May 2020.

15. Chen P, Mao L, Nassis GP, Harmer P, Ainsworth BE, Li F. Returning Chinese school-aged children and adolescents to physical activity in the wake of COVID-19: Actions and precautions. J Sport Heal Sci. 2020; 9(4): 322-324. DOI:10.1016/j. jshs.2020.04.003

16. Cuschieri S, Grech S. COVID-19: a one-way ticket to a global childhood obesity crisis? J Diabetes Metab Disord. 2020; 19(2):1-4. DOI: 10.1007/s40200-020-00682-2

17. Kriaucioniene V, Bagdonaviciene L, Rodríguez-Pérez C, Petkeviciene J. Associations between changes in health behaviours and body weight during the COVID-19 quarantine in Lithuania: The Lithuanian COVIDiet Study. Nutrients. 2020; 12(10):3119. DOI: $10.3390 /$ nu12103119

18. World Health Organization. (2020). \#HealthyAtHome - Physical activity. Available at: https://www.who.int/news-room/ campaigns/connecting-the-world-to-combat-coronavirus/healthyathome/healthyathome---physical-activity. Accessed: 19 May 2020.

19. Guan H, Okely AD, Aguilar-Farias N, del Pozo Cruz B, Draper CE, El Hamdouchi A, et al. Promoting healthy movement behaviours among children during the COVID-19 pandemic. The Lancet Child and Adolescent Health. 2020;4(6):416-418. DOI:10.1016/S2352-4642(20)30131-0

20. Yang GY, Lin XL, Fang AP, Zhu HL. Eating habits and lifestyles during the initial stage of the covid-19 lockdown in china: A cross-sectional study. Nutrients. 2021;13(3):970. DOI: 10.3390/nu13030970.

21. Pietrobelli A, Pecoraro L, Ferruzzi A, Heo M, Faith M, Zoller T, et al. Effects of COVID-19 lockdown on lifestyle behaviors in children with obesity living in Verona, Italy: A Longitudinal Study. Obesity. 2020;28(8):1382-5. DOI:10.1002/oby.22861

22. Adıbelli D, Sümen A. The effect of the coronavirus (COVID-19) pandemic on health-related quality of life in children. Child Youth Serv Rev. 2020;119:105595. DOI:10.1016/j.childyouth.2020.105595

23. Pellegrini M, Ponzo V, Rosato R, Scumaci E, Goitre I, Benso A, et al. Changes in weight and nutritional habits in adults with obesity during the "lockdown" period caused by the COVID-19 virus emergency. Nutrients. 2020;12(7):1-11. DOI:10.3390/ nu12072016

24. Deschasaux-Tanguy M, Druesne-Pecollo N, Esseddik Y, de Edelenyi FS, Allès B, Andreeva VA, et al. Diet and physical activity during the COVID-19 lockdown period (March-May 2020): Results from the French NutriNet-Santé cohort study. Am J Clin Nutr. 2020; 6;113(4):924-938. DOI:10.1101/2020.06.04.20121855

25. Storz MA. The COVID-19 pandemic: an unprecedented tragedy in the battle against childhood obesity. Clin Exp Pediatr. 2020;63(12):477-82. DOI:10.3345/cep.2020.01081

26. Dondi A, Candela E, Morigi F, Lenzi J, Pierantoni L, Lanari M. Parents' perception of food insecurity and of its effects on their children in Italy six months after the COVID-19 pandemic outbreak. Nutrients. 2020;13(1):121. DOI:10.3390/ nu13010121

27. Adams EL, Caccavale LJ, Smith D, Bean MK. Food insecurity, the home food environment, and parent feeding practices in the era of COVID-19. Obesity. 2020;28(11):2056-63. DOI:10.1002/oby.22996 